International Journal of Social Sciences and Humanities
Available online at http://sciencescholar.us/journal/index.php/ijssh
Vol. 2 No. 1, Appril 2018, pages: $33 \sim 42$
e-ISSN: 2550-7001, p-ISSN: 2550-701X
http://dx.doi.org/10.29332/ijssh.v2n1.76

\title{
Implementation of Tourism Facilities Expansion to Hedonism and Community Imaging
}

A. A. Gde Putra Pemayun ${ }^{\text {a }}$ Ida Bagus Brata ${ }^{\text {b }}$
Article history: Received 10 June 2017, Accepted in revised form 11 January 2018, Approved 3 February 2018,
Available online 7 February 2018

a Undiknas University, Denpasar, Bali-Indonesia

b Undiknas University, Denpasar, Bali-Indonesia 


\section{Contents}

Abstract

1. Introduction

2. Research Metho

3. Results and Analysis

4. Conclusion

Acknowledgements

References

\section{Introduction}

Globalization cannot be separated with the progress of science, information technology, and telecommunications holistically. The influence of global culture flows at Kutuh Ubud Gianyar has implications for cultural practices of capitalism, such as the emergence of a cultural industry that refers to the touristification of cultural forms, as the entertainment industry, mass culture, popular culture, and consumer culture. Cultural tours are in line with the services offered by the tourism industry by selling standard, standard, deluxe and suite room services, as well as performing arts, attractions, architecture, cuisine, as tour packages. The common feature of the accommodation facility is to utilize terraces, cliffs and scenic river as the location of the hotel. This accommodation facility complements the image of Kutuh Village Ubud Gianyar as a typical tourist village regarding structure, nature, and modern tastes. As a blend of high touch and high tech simultaneously offers a distinctive charm and image as an international village.

The working community has a specific purpose that is to meet the needs. Needs cannot be separated from everyday life, during human life requires a variety of needs, such as food, clothing, housing, education, and health. Needs are influenced by culture, environment, time, and religion. The higher the cultural level of a society, the higher the need to be fulfilled. Physiological needs are the most basic and greatest potential for all the fulfillment of the above needs. Hungry people will always be motivated to eat, not to make friends or be rewarded. The Kutuh Ubud Gianyar community will ignore or suppress all other needs until their physiological needs are satisfied. If the Kutuh Ubud Gianyar community is already established, the need to satisfy hunger as a lifestyle. They usually have enough food, but when they say hunger then what they think is the taste of food to be chosen, not the hunger he feels. Someone who is hungry will not be too concerned with the taste, smell, temperature or texture of food.

Hedonism according to Aristotle in Russell (2004: 243) pleasure is different from happiness because there can be no happiness without pleasure. Said three views of pleasure: (1) all pleasures are not good; (2) some good pleasures, but mostly bad; (3) good enjoyment, but not the best. Aristotle rejected the first opinion because suffering is certainly bad, so pleasure is certainly good. Rightly he says that it is absurd to say that humans can be happy in suffering: good luck whose nature is outward, to some extent, necessary for the realization of happiness. He also denies the view that all pleasures are physical; everything contains a spiritual element, and pleasure contains so many possibilities for the enjoyment of ever-present pleasurable pleasures. Furthermore, it is said to be a bad pleasure, but it is not the pleasure felt by good people, it may be different enjoyment. Lifestyle affairs are not just a monopoly of moneyed people either; not even the poor can still use certain hedonistic models even if they are just playing, imitating, or pretending, just as the rich can also pretend to be poor. Not because adhere saving or ascetic ideology is not because of the influence of simple lifestyle campaigns, but because of lifestyle choices. For the community of Kutuh Ubud Gianyar modern matter of imaging and lifestyle is not clear any more limits. In the discourse of capitalism, everything produced by capitalism will eventually be deconstructed by subsequent new production under the laws of progress and novelty. 


\section{Literature Review}

Until now, a special study on the implementation of tourism Expansion of Hedonism and Imaging of Kutuh Ubud and Bali communities is still very minimal. However, some of the results of studies that have been conducted that are relevant and can be used as references in this study can be put forward as follows. Based on the study of studies on Ubud more focused on the problem of painting and tourism. Several studies have been conducted in the village of Ubud in the last fifteen years, among others (Picard, 2006) with a book entitled Tourism Culture and Tourism Culture (Ubud Case Study). The results of this study indicate that the area of Ubud attracts tourists who want to see Bali in its artistic and ceremonial image. They want to see the original Balinese village. Every day Ubud is flooded with hundreds of special tourists coming from Nusa Dua, Sanur, and Kuta to see the village painter. Also, many visitors to learn the arts that have become a source of fame Ubud Village, the art of dance, sculpture, and painting. So the focus of this study describes the development of tourism and the increasing number of local artists interested in pursuing her ancestral art heritage to remain sustainable.

Tjokorda Arta Ardana Sukawati (2010) conducted research entitled "Social Change of Ubud Traditional Village, Gianyar, Bali in the Era of Globalization of Cultural Studies." In that research, the socio-cultural and socio-economic situation of the readiness of the people of Ubud in anticipation of the impact caused by the lack of distance between countries in the world due to the increasingly widespread globalization swept the world. So, the focus of this study is ready to be unprepared by the Ubud community already in the era of globalization that is rapidly sweeping across all aspects of community life including the social changes caused by the current globalization.

\section{Research Method}

The data used in this research are:

a. Primary data, i.e., data, and information obtained directly from sources/respondents. This data was obtained by interviewing the Kutuh Ubud Gianyar community home which rented land for tourism expansion, as a research sampling unit. The population of this study is all of Kutuh Ubud Gianyar community who rent the land by using proportional sampling technique with a sample of 27 people.

b. Secondary data, namely data and supporting information obtained from the office of Kutuh Village Ubud Gianyar and other relevant data.

\section{Research Sites}

Research location in Kutuh Village Ubud Gianyar by observing and mapping the community who rent the land for the expansion of tourism. The observation time as an object of analysis is the condition of 1 (one) year running in 2017. 2017 usage considerations are taken to facilitate the recording of information to the respondents, i.e., the Kutuh Ubud community who rent the land for the expansion of tourism.

\section{Research instrument}

The instruments used in this study are qualitative descriptive research through literature surveys and field surveys and in-depth interviews. The interviews were open-ended questions and closed-ended questions.

\section{Data analysis method}

The method of analysis used in this study includes several methods by the objectives of the study are as follows.

1) The theory of Hedonism used to analyze society into hedonists, divide consumption behavior into three periods with the social conditions of each surrounding. These three periods, namely the classical period, the emergence of consumption sociology, and the postmodernist period, connect consumption with social symbols in society.

2) Hierarchy Theory The need to describe the real condition that needs at a low level must be fulfilled or at least sufficiently met first before higher-level needs become motivating. Maslow also said that the need for love includes the love that gives and the love that it receives. Society must understand love,

Pemayun, A., \& Brata, I. (2018). Implementation of Tourism Facilities Expansion to Hedonism and Community Imaging. International Journal Of Social Sciences And Humanities (IJSSH), 2(1), 33-42. doi:10.29332/ijssh.v2n1.76 
must be able to teach it, create it and predict it. Otherwise, the world will drift into a wave of animosity and hatred.

a. Observation Techniques and Interviews

Observation is conducted by observing directly in the field so that it can see and observe more carefully about the condition of the location that is rented as the expansion of tourism. In-depth interviews (In-depth Interview) with some informants who have set 27 people.

b. Documentation Study

Documentation study is data collection techniques by taking some documents or mass notes ago, both on the people who rent the land in Kutuh Ubud Gianyar and relevant agencies.

\section{Results and Analysis}

\subsection{Epicurus and Russell Hedonism}

Theory Hedonism is a worldview that assumes that people will be happy by seeking as much happiness as possible and avoiding painful feelings as much as possible. Hedonism is the doctrine that pleasure or pleasure is the goal of human life and action. Hedonism has become the grip of the community Kutuh Ubud Gianyar many noble values of humanity fade, even disappear. Their social sensitivity threatened to be displaced when they always consider the profit and loss in socializing. The Kutuh Ubud Gianyar community looks like a living mummy that is of no use to them. They seem to be a royal guard of pleasure that no one can sniff let alone taste it. Other people can only gawk at their establishment. They do not care. As a result, when there are people who need a helping hand, they hide and are reluctant to make sacrifices. The cause of hedonism due to external factors namely the rapid flow of industrialization and globalization that attacks the community Kutuh Ubud Gianyar is an inevitable factor. Values that were once considered taboo are now considered normal. Media communication, especially the advertising media is very tangent to ethical and moral issues. Through imaginative symbols, mass communication media obviously take into account and take advantage of passions, feelings, and desires. Currently, hedonists promote a variety of offers of human needs until the life of the world sparkling night porn action through the action of television media, advertising and other print media (Budi Santoso, 2016: 69).

Hedonistic behavior cannot be separated from the association of fellow in big cities who prefer pleasure and enjoyment. In associating there is always pressure from within the community of Kutuh Ubud Gianyar to do the same with the group. If someone lives in an environment that pleasure-loving life, the pursuit of pleasure, then naturally the person will follow a lifestyle that has been invested in the social environment. Theo Huijbers sometimes say because of being pressured problem demanding economic needs; the metropolitan community can drift increasingly hedonistic consumerism. While the internal factors, the weakness of one's religious beliefs also affect the behavior of some communities Kutuh Ubud Gianyar which glorify the fun and mere hura-rah. Binzar Situmorang (2016:72) stated that "Spirituality someone become a benchmark in everyday life, especially for those who love the pursuit of pleasure.

Hedonism is a lifestyle that emphasizes and elevates material-physical pleasure during life on earth. Ubud Kiani Gianyar people who have a hedonistic lifestyle always assume that heaps of property, position, rank, position, and the like that is outwardly is happiness and joy. The era of globalization of many people Kutuh Ubud Gianyar follows the hedonic lifestyle because at this time many media that offer a fun life with modern style, consumptive, and genset. Lifestyle ideas that are demanded and pursued as perpetrators of modern life are free life without boundaries, both ethics of ethics, moral, and morals. It is also motivated by the tightness of the world of competition, especially in the field of economy and the principles of the fulfillment of needs and unlimited desires. The hedonic lifestyle of this society is not sensitive to the circumstances, but always do things according to desire, not care about the surrounding environment.

In an uncertain condition, they are living a life spree with the luxury of a sophisticated facility. Ironically, all the goods are not necessarily bought from their own money. Some holders of power use vehicles and facilities from corrupt money, while most of those who rent the land in Kutuh Ubud have a luxurious lifestyle of debt or from something unclear. This attitude is what experts call the hedonic lifestyle. Ubud Kiani Gianyar people spend more money for activities that are not clear or all amusement. Important considerations at least activity is no longer a priority, more importantly, it can bring happiness for a moment. Look how the community is competing with luxury, homes, vehicles, mobile phones, and other luxury facilities. 
All that often is not based solely on necessity, but the emphasis is more on the value of prestige or pride alone. As a result, for those who cannot afford to be tempted to do everything to follow the trend of today. Hedonis like this is an illusion. The illusion gives false happiness. Happiness in a dream that will eventually disappoint itself. It is said so because without realizing it, the cost of living is too great to be wasted (Emanuel Subangun, 2004: 96). Affirmed that this action as something deadly. How not, luxury goods enjoyed by the community Kutuh Ubud Gianyar is imported goods. That is why all spending spent is not for the progress of the nation itself, but for other nations that are economical, socially, politically colonized. That is the most profound ignorance in the individual.

Hedonist and materialist attitudes have also created unhealthy competition amongst people. The existence of this attitude creates an unhealthy social gap. On the other hand, there is a class full of luxury, while others live within limitations. With concern and simplicity, there needs to be a re-awareness of these commendable characteristics. It is important because over time this society will be destroyed due to the attitude of its people who do not support development in this country. The current orientation of wealth will be greatly influenced by the lifestyles of future generations, even at the leader level in the country. Operationally hedonism is the lifestyle of the community Kutuh Ubud Gianyar which emphasizes and elevates the material-physical pleasure during life on earth. Hedonistic groups always assume that heaps of property, position, rank, position, and the like that is outward is happiness and joy. With a hedonist there is selfishness, regard everything as a matter of personal affairs as a human right. So it will not care what others think about what he does. Always indifferent about his or her lifestyle judgment that is good or not. Other factors that cause the tendency of hedonism is the culture of Kutuh Ubud Gianyar community and the surrounding environment. In a community of Kutuh Ubud Gianyar that has a luxurious living culture, the tendency to luxury will dominate all members of society. In this case, the luxuries of officials and public figures will have a tremendous impact on this lifestyle. The mass media factor in this contemporary and digital era of advertising contained in various media means helped to create a culture of hedonism. These media in many cases advertise products that are not needed. These ads also leave behind the psychological impacts on the hedonists. Many of the harm caused by hedonism. First, the disappearance of wealth, increasing the gap between poor and rich poverty, bankruptcy and debt in the midst of small communities. Ibn Khaldun historian and Muslim sociologist in this regard said: To what extent society is immersed in hedonism, so far they will approach the limit of destruction (Ibn Khaldun, 2016: 37). The process of destruction will occur because hedonism will slowly cause poverty in society and the state.

The extent to which hedonism epidemic, so far poverty will spread in the community. On the other hand, wasting a fortune to buy expensive things that are only meant to be proud of, will gradually drag a country to a foreign party. It is what is happening right now in the world. Many countries in the world depend on the West who at all times market new products for consumption. Though the work, effort and effort to seek treasure, can lead a person and his community to progress but do not let that fall into the valley of hedonism.

\subsection{Abraham Maslow's Hierarchy of Needs Theory}

The concept of the basic needs hierarchy of the community Kutuh Ubud Gianyar, takes precedence over the needs of others. As the need for clothing, food and home, people feel thirsty, then people will tend to try to quench thirst. People can live without food for weeks. But without water, the individual can live for only a few days because the need for water is stronger than the need for food. These needs are often called Abraham Maslow as the basic needs described as a hierarchy or ladder depicting the level of need. There are five levels of needs, namely: (1) Physiological Needs (Physiological Needs) or the most basic needs of every person Kutuh Ubud Gianyar namely the need to maintain his life physically. These needs are like the need for food, drink, shelter, sleep and oxygen (clothing, food, boards). Physiological needs are the most basic and greatest potential for all the fulfillment of the above needs. Hungry man will always be motivated to eat, not to make friends or appreciate. Man will ignore or suppress all other needs until his physiological needs are satisfied. In the already established community of Kutuh Ubud Gianyar, the need to satisfy hunger is a lifestyle. They usually have enough food, but when they say hunger then what they really think is the taste of food to be chosen, not the hunger he feels. Someone who is really hungry will not be too concerned with the taste, smell, temperature or texture of food. Physiological needs differ from other

Pemayun, A., \& Brata, I. (2018). Implementation of Tourism Facilities Expansion to Hedonism and Community Imaging. International Journal Of Social Sciences And Humanities (IJSSH), 2(1), 33-42. doi:10.29332/ijssh.v2n1.76 
needs in two ways. First, the physiological need is the only requirement that can be fully satisfied or minimally insurmountable. Humans can feel enough in the activity of eating so that at this point, the driving force to eat will be lost. For someone who has just completed a great meal, and then imagining a food again is enough to make her nauseous. Second, that is typical in physiological needs is the essence of repetition. After humans eat, they will eventually become hungry again and will continue to search for food and water again. While the needs of the higher levels do not continue to emerge. For example, a person who is at least partially fulfilled their need to be loved and appreciated will still be confident that they can maintain the fulfillment of those needs without having to look for them again. (2) The Need for Safety (Security / Security Needs). Once the physiological needs are adequately satisfied, what Maslow calls the needs of security. These security needs include physical security, stability, dependence, protection and freedom from threatening powers such as crime, war, terrorism, disease, fear, anxiety, anger, unrest and natural disasters. As well as psychic needs that threaten psychiatric conditions such as not mocked, not humiliated, not stressed, and so forth. The need for security is different from physiological needs because this need cannot be completely fulfilled. Humans can never be protected completely from the threats of meteors, fire, flood or other dangerous behavior. According to Maslow, unsafe people will behave just like unsafe children. They will behave as if always in great danger. An insecure person has a need for excessive order and stability and will try hard to avoid things that are foreign and unexpected. (3) The Need for Sense of Ownership and Social Needs. If the physiological needs and the need for security have been met, then the need for love, affection and belonging has arisen. These needs include encouragement to be needed by others to be regarded as citizens of their social community. This form of fulfillment needs such as friendship, the desire to have a partner and heredity, the need to be close to family and interpersonal needs such as the need to give and receive love. Someone whose love needs have been relatively fulfilled since childhood will not feel panic when rejecting love. He will have great confidence that he will be accepted by people who are important to him. When someone else rejects him, he will not feel crushed. For Maslow, love involves a healthy and loving relationship between two people, including mutual trust. Often love becomes corrupted if one party fears its weaknesses and mistakes. Maslow also said that the need for love includes the love that gives and the love that it receives. The community of Kutuh Ubud Gianyar must understand love, must be able to teach it, create it and predict it. Otherwise, the world will drift into a wave of animosity and hatred. (4) Esteem Needs. Once the needs are loved and possessed sufficient, then man will be free to pursue his ego needs on the desire to excel and have prestige. Maslow found that everyone in Kutuh Ubud Gianyar had two categories of reward needs, namely lower and higher needs. Low needs are the need to respect others, the need for status, fame, glory, recognition, attention, reputation, appreciation, dignity, even domination. High demand is the need for self-esteem including feelings, beliefs, competencies, achievements, mastery, independence and freedom. Once humans can meet the need to be respected, they are ready to enter the gates of self-actualization. (5) The Need for Self-actualization Needs (Maslow in Sobur, 2003: 72). The last level of Abraham Maslow's basic needs is self-actualization, namely the need to prove and show himself to others. At this stage, the community of Ubud Gianyar Kutuh develop as much as possible all the potential he has. The need for self-actualization is a need that does not involve balance, but involves a constant desire to fulfill potential. Maslow describes this need as a desire to become fully self-worth, to be anything according to his ability. Maslow hypothesized that after the community of Kutuh Ubud Gianyar satisfies the needs at the lowest level, society will satisfy the needs at the next level. If at the highest level but basic needs are not satisfied, then the community can return to the level of previous needs. According to Maslow, the satisfaction of various needs is driven by two forces namely deficiency motivation and growth motivation (Maslow in Sobur, 2003: 89). The motivation of deficiency aims to overcome the problem of human tension due to various shortcomings. While the growth motivation is based on the capacity of every human being to grow and develop. Capacity is the nature of every human being.

\section{Conclusion}

To understand the various variations of the implementation of the expansion of tourism facilities to hedonism and community imaging in Kutuh Ubud Gianyar after the lease of land, the dimensions of the times, the globalization of tourism, and the powers of change, both internal and external. Another thing is the power, money, and actors who play so that efforts to analyze the hedonic dimension and image of 
society that leases the land and the power of capitalism internally and externally needs to be done. Accordingly, the conclusions drawn from the results of the study are as follows.

Firstly, Hedonism among the Kutuh Ubud Gianyar community has grown tremendously with the development of the times, a mindset that only concerns the pleasure of making this society lulled into a sometimes unrealistic life. Another factor that causes the tendency of hedonism is the culture of Kutuh Ubud Gianyar community and the surrounding environment. In a community of Kutuh Ubud Gianyar that has a luxurious living culture, the tendency to luxury will dominate all members of society. In this case, the luxuries of officials and public figures will have a tremendous impact on this lifestyle. The mass media factor in this contemporary and digital era of advertising contained in social media helped create a culture of hedonism. These media in many cases advertise products that are not needed.

Second, Imaging practices subsequently become a community lifestyle. Imagery becomes a new worldview of society. Along with the continuous operation of cross-country industry and the growth of supermarkets, hypermarkets, and malls. In fact, with its beautiful strategy, consumer goods are adapted to the experiences and philosophical views of the local community (Fordism). Human needs because of its nature is endless then prioritize the basic needs first. After that just meet the needs of a secondary or tertiary. For some unmet needs required hard work in sufficient The fulfillment of needs according to this Maslow is expected to make the life of the community Kutuh Ubud Gianyar more peaceful. The construction of a society of capitalism which views production as the driving force of the economy must now be rebuilt that capitalist society sees to consume as an economic driver. Globalization as a process is characterized by the absence of borders between countries in the world.

\section{Recommendation}

First, to fortify themselves from hedonism and imagery that offers only momentary pleasure, it must start from the self as well as the support of others. For the people who rent the land in Kutuh Ubud Gianyar should increase self-control so that the lease of land can be used for more productive purposes. Embed the attitude of life sparingly among families, many useful things that can be done without having a spree.

Secondly, this study is a preliminary study on hedonism and community imaging in Kutuh Ubud Gianyar. This study traces the behavior of hedonism and community imaging that receives land rent for expansion of tourism facilities. In this research has been disclosed behavior of hedonism and community imaging in brief, but has not been studied in depth so that needed further research comprehensively.

\section{Acknowledgements}

Our deep and sincere gratitude were presented to God for having granted us the ability and the opportunity to complete this paper. We would also like to thank our former lecturers and our friends for their support, their patience, their contribution, and their valuable input, therefore, this article could be completed. We would also thank I Wayan Suryasa as an advisor as well as editor in chief of IJCU, IJMRA, SKIREC, Euro Asia as well as ScienceScholar who has reviewed and approved this study to be published.

Pemayun, A., \& Brata, I. (2018). Implementation of Tourism Facilities Expansion to Hedonism and Community Imaging. International Journal Of Social Sciences And Humanities (IJSSH), 2(1), 33-42. 


\section{References}

1. Appadurai, A. (1996). Modernity al large: cultural dimensions of globalization (Vol. 1). U of Minnesota Press. View in (Google Scholar)

2. Sotiris, P. (2009). Louis Althusser Louis Althusser and the Traditions of French Marxism Althusser: The Detour of Theory. Historical materialism, 17(4), 121-142.

View in (Google Scholar)

3. Baudrillard, J. (1998). The Drama of Leisure or the Impossibility of Wasting One's Time The Consumer Society: Myths and Structures (pp. 151-158).

View in (Google Scholar)

4. Chaney, D. (1996). Lifestyles: sebuah pengantar komprehensif. Yogyakarta: Jalasutra.

View in (Google Scholar)

5. Satori, D. A. Aan. 2012. Metodologi Penelitian Kualitatif. Bandung: Alfabeta.

View in (Google Scholar)

6. Schrader, H. (1994). A Discussion of Trade in Social Science. HD Evers and H. Schrader (eds): The Moral Economy of Trade.

View in (Google Scholar)

7. Featherstone, M. (2005). Postmdernisme dan Budaya Konsumen, terj. Misbah Zulfa Elizabeth, Yogyakarta: Pustaka Pelajar.

View in (Google Scholar)

8. Giddens, A. (1994). Beyond left and right: The future of radical politics. Stanford University Press. View in (Google Scholar)

9. Feist, J., \& Feist, G. J. (2010). Teori kepribadian. Jakarta: Salemba Humanika. View in (Google Scholar)

10. Goble, F. G. (1987). Mazhab Ketiga, Psikologi Humanistik Abraham Maslow. Kanisius. View in (Google Scholar)

11. Habermas, J. (2007). Teori Tindakan Komunikatif I: Rasio dan Rasionalisasi Masyarakat (terjemahan: Nurhadi). Yogyakarta: Kreasi Wacana, cetakan ke dua.

View in (Google Scholar)

12. Ibrahim, I. S. (2007). Budaya populer sebagai komunikasi: dinamika popscape dan mediascape di Indonesia kontemporer. Jalasutra.

View in (Google Scholar)

13. Moleong, J. (2011). Lexy, Metode Penelitian Kulalitatif, Bandung: Pt Remaja Rosdakarya, cet. View in (Google Scholar)

14. Sobur, A. (2003). Psikologi umum dalam lintasan sejarah. Bandung: Pustaka Setia. View in (Google Scholar)

15. Astawa, I. N., Mantra, I. B. N., \& Widiastuti, I. A. M. S. (2017). Developing Communicative English Language Tests for Tourism Vocational High School Students. International Journal of Social Sciences and Humanities (IJSSH), 1(2), 58-64.

View in (Google Scholar) 
16. Amerta, I. M. S. (2017). The Role of Tourism Stakeholders at Jasri Tourism Village Development, Karangasem Regency. International Journal of Social Sciences and Humanities (IJSSH), 1(2), 20-28.

View in (Google Scholar)

17. Mardika, I. N. (2017). Opposition of Community Citizenship Against the Policy of the Village's Leader. International Journal of Social Sciences and Humanities (IJSSH), 1(3), 74-87.

View in (Google Scholar)

18. Amerta, I. M. S. (2017). Community Based Tourism Development. International Journal of Social Sciences and Humanities (IJSSH), 1(3), 97-107.

View in (Google Scholar)

19. Pemayun, A. G. P., \& Maheswari, A. I. A. (2017). Economic Impacts of Craftsman Statue on Community Based Tourism Development. International Journal of Social Sciences and Humanities (IJSSH), 1(3), 59-73. View in (Google Scholar)

20. Meza, A. K. T., Freyre, J. R. A., Cevallos, M. G. O., \& Pico, M. J. M. (2018). Autonomy, Good Humor and Support Networks, Potential of Community Resilience Intervention in People Victims of the Earthquake in the Calderón Parish. International Research Journal of Management, IT and Social Sciences (IRJMIS), 5(1), 1-8. View in (Google Scholar)

21. Wisudawati, N. N. S., \& Maheswari, A. I. A. (2018). Potential of Silver Craft Product through to CommunityBased for Tourism Sustainability in Celuk Village. International Research Journal of Management, IT and Social Sciences (IRJMIS), 5(1), 9-15.

View in (Google Scholar)

22. Ashworth, G., \& Page, S. J. (2011). Urban tourism research: Recent progress and current paradoxes. Tourism management, 32(1), 1-15.

View in (Google Scholar)

23. Getz, D., \& Page, S. J. (2016). Progress and prospects for event tourism research. Tourism Management, 52, 593-631.

View in (Google Scholar)

24. Moufakkir, 0., \& Kelly, I. (2012). 8 Peace through tourism A sustainable development role for. Events, Society and Sustainability: Critical and Contemporary Approaches, 130.

View in (Google Scholar)

Pemayun, A., \& Brata, I. (2018). Implementation of Tourism Facilities Expansion to Hedonism and Community Imaging. International Journal Of Social Sciences And Humanities (IJSSH), 2(1), 33-42. doi:10.29332/ijssh.v2n1.76 


\section{Biography of Authors}

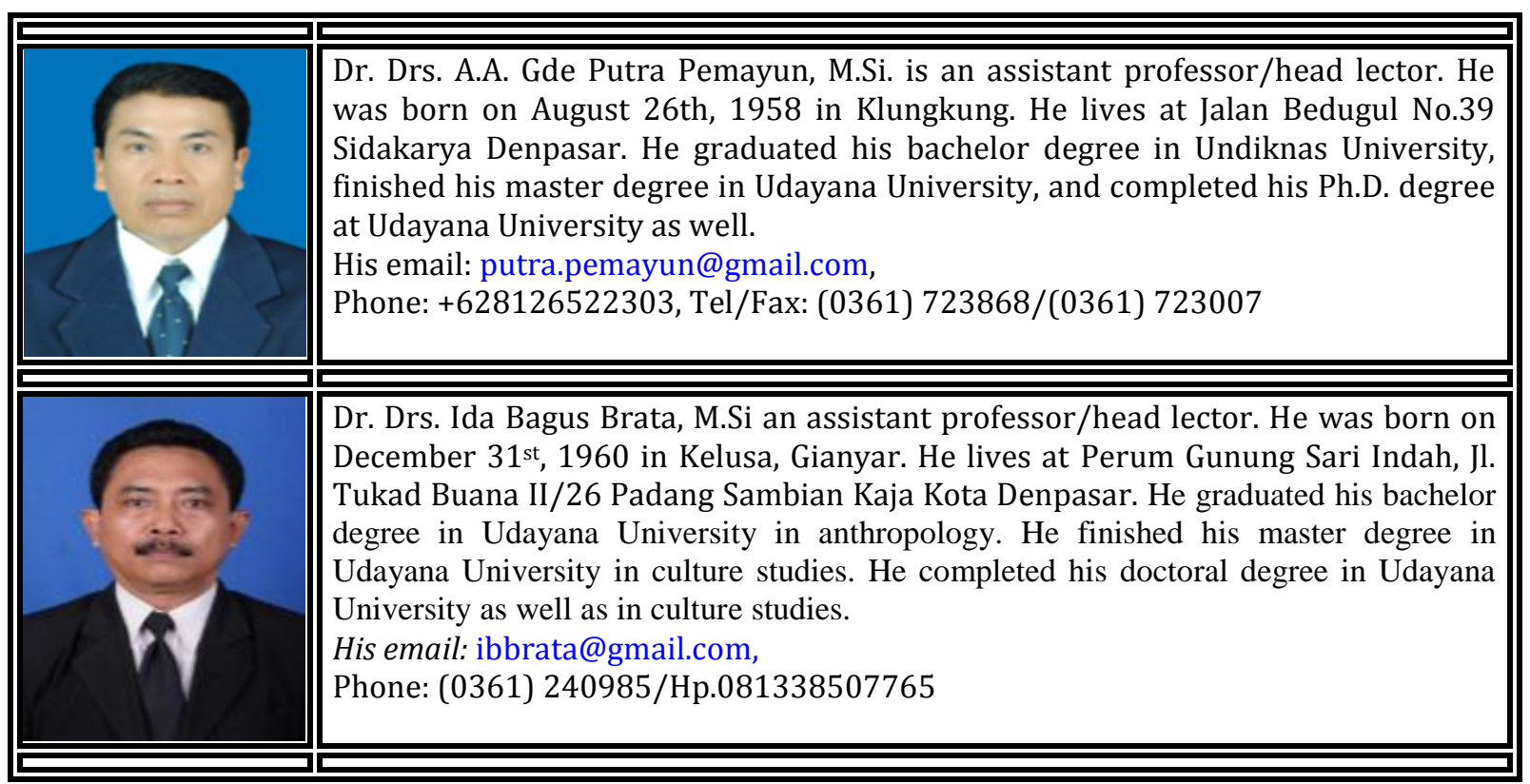

